\title{
Pengembangan Usaha Budidaya Ikan Lele (Clarias sp.) Dalam meningkatkan kualitas dan harga jual di masa pandemi covid 19 di Desa Nologaten Kabupaten Ponorogo Provinsi Jawa Timur
}

\author{
Muhammad Furqon Shofari \\ Pengembangan Masyarakat Islam, Dakwah, Insuri Ponorogo \\ fqon694@gmail.com
}

\begin{abstract}
ABSTRAK
Salah satu komoditas perikanan yang sangat prospektif untuk dibudidayakan dalam skala industridan rumah tangga adalah ikan lele (Clarias sp.). Tujuan kajian ini: (1) menganalisis kelayakan budidayaikan lele di DesaNologatendi Kabupaten Ponorogo, Jawa Timur (2) menganalisa potensi Kualitas ikanlele di Masa Pandemi Covid 19, (3) meningkatkan harga nilai jual pada masa Pandemi covid 19 di Desa Nologaten Kabupaten Ponorogo Jawa Timur. Metode yang digunakan dalam penelitian ini adalah metode deskriptif yang berfokus padaaspek teknis dan budidaya pengembangan usaha, serta analisis Asset, Based, CommunitydanDevelopment $(A B C D)$. Berdasarkan analisis kelayakan memiliki prospek yang menjanjikan dan layak untukdikembangkan. Untuk memaksimalkan pendapatan petani lele, kombinasi strategiBased, strategiCommunity danstrategi Development merupakan strategi yang tepat untuk dipilih petani. Untuk memaksimalkan pendapatanpembudidaya ikan lele, dilakukan penambahan jumlah dan luas kolam dan mencari alternative pakan lele, serta mengembangkan usahabudidaya, menerapkan cara-cara pemeliharaan dan budidaya yang baik, serta memperluas jangkauanpasar mulai dari konsumen perorangan, pasar tradisional rumah makan dan restoran hingga ke pasarmodern untuk meningkatkan efisiensi modal dan meningkatkan keuntungan bagi petani lele pada masa pandemic covid 19 diDesa Nologaten, Kabupaten Ponorogo, Jawa Timur.
\end{abstract}

Kata kunci:pengembangan usaha, ikan lele,budidaya,dimasa Pandemic covid 19

\section{ABSTRACT}

One of the fishery commodities that are very prospective to be cultivated on an industrial and household scale is catfish (Clarias sp.). The aims of this study: (1) analyze the feasibility of catfish farming in Nologaten Village, Ponorogo Regency, East Java (2) analyze the potential quality of catfish during the Covid 19 Pandemic, (3) increase selling prices during the Covid 19 Pandemic in Nologaten Village, Ponorogo Regency, East Java. The method used in this study is a descriptive method that focuses on the technical aspects and cultivation of business development, as well as Asset, Based, Community and Development (ABCD) analysis. Based on the feasibility analysis, it has promising prospects and deserves to be developed. To maximize the income of catfish farmers, a combination of Based strategy, Community strategy and Development strategy is the right strategy for farmers to choose. Maximizing the income of catfish cultivators, increasing the number and area of ponds and looking for alternative catfish feed, as well as developing aquaculture businesses, implementing good maintenance and cultivation methods, and expanding market reach ranging from individual consumers, traditional markets for restaurants and restaurants to modern markets to increase capital efficiency and increasing profits for catfish farmers during the COVID-19 pandemic in Nologaten Village, Ponorogo Regency, East Java. 
Keywords: business development, catfish, cultivation, during the Covid-19 Pandemi

\section{PENDAHULUAN}

Indonesia merupakan negara dengan tingkat pertumbuhan penduduk semakin tinggi dari tahun ke tahun. Hal ini menyebabkan tingkat kebutuhan konsumsi protein yang berasal dari ikan semakin meningkat. Salah satu komoditas perikanan yang sangat prospektif untuk dibudi-dayakan dalam skala industri maupun rumah tangga adalah ikan lele (Clarias sp.). Untuk Di Indonesia jenis ikan lele mempunyai beberapa nama Unik di masing - masing daerah, antara lain yaitu ikan kalang (Padang), ikan maut(Gayo, Aceh), ikan pintet (Kalimantan Selatan), ikan keling (Makasar), ikan cepi (Bugis), ikan leleatau lindi (Jawa Tengah) (Kantor Deputi Meneg-ristek Bidang Pendayagunaan dan Pemasyarakat-an Ilmu Pengetahuan dan Teknologi, 2000). Empat variasi warna ikan lele yang diperjual-belikan, yakni hitam, putih, merah dan belang. Ikan lele konsumsi biasanya berwarna hitam kelabu, sedangkan yang berwarna putih, merah dan belang umumnya diperjual belikan sebagai ikan hias karena keunikan warna ikan tersebut yang jarangada pada ikan umumnya (Gunawan2009).

Produksi ikan lele ukuran konsumsi secaranasional mengalami kenaikan 18,3\%/tahun yaitudari24.991 ton pada tahun 1999 menjadi57.740ton pada tahun 2003. Revitalisasi ikan lele sampai dengan akhir tahun2009 ditargetkan mencapai produksi175.000 ton atau meningkat rataan 21,64\%/ tahun. Kebutuhan benih ikan lele mengalami peningkatan pesat yaitu dari 156 jutaekor pada tahun 1999 menjadi 360 juta ekor padatahun 2003 atau meningkat rataan 46\% / tahun.Kebutuhan benih lele diperkirakan mencapai 1,95 miliar ekor pada akhir 2009 (Mahyuddin 2010).

Secara umum terdapat dua alasan perlunya peningkatan konsumsi ikan masyarakat, yaitu pertama adalah untuk meningkatkan mutu sumber daya manusia(SDM) Indonesia dengan meningkatnya asupan masyarakat akan protein dan gizi yang berasal dari ikan, serta kedua adalah peningkatan konsumsi ikan, akan mendorong pengembangan industriikan lele diIndonesia, khususnya dalam aspek pemasaran dan pengolahan. Dahulu ikan lele dipandang ikan murahan dan hanya dikonsumsi oleh keluarga petani, sekarang ikan lele merupakan komoditasyang sangat disukai oleh masyarakat (Sukardonoel al, 2013). Selain itu rasa daging yang khas, serta cara memasak dan menghidangkan secara tradisional, menjadikan menu sajian ikan leled igemari masyarakat luas (Jajaetal,2013).

Alih guna lahan-lahan produktif menjadi daerah pemukiman membuat lahan yang dapat dimanfaatkan, terutama untuk usaha budidaya dibidang perikanan menjadi terbatas. Salah satu solusi untuk mengatasinya dengan pemanfaatan lahan non-produktif atau lahan-lahan marginal 
sebagai media budidaya dibidang perikanan, seperti budidaya lele dengan kolam terpal. Ketahanan lele diair yang tidak mengalir membuat budidaya lele mudah diterapkan meskipun pada lahan sempit dan kering. Usaha budidaya lele tidak membutuhkan biaya besar, mudah dan waktu pemeliharaannya singkat, sehingga cepat memberikan hasil bagi pembudi-dayanya. Berbeda dengan jenis ikan lain yang sangat rentan terhadap penyakit, lele tidak mem-butuhkan perhatian khusus saat pemeliharaan.

Berdasarkan latar belakang,tujuan dari kajian ini adalah(1) menganalisis kelayakan budidayaikan lele di DesaNologatendi Kabupaten Ponorogo, Jawa Timur (2) menganalisa potensi Kualitas ikanlele di Masa Pandemi Covid 19, (3) meningkatkanharganilaijual pada masa Pandemi covid 19 di Desa Nologaten Kabupaten Ponorogo Jawa.

\section{METODOLOGI PENGABDIAN}

Untuk mewujudkan kondisi subyek dampingan yang diharapkan, maka perlu strategi dan metodologi dalam program pendampingan pemberdayaan untuk peningkatan jiwa wirausaha dalam menetaskan kemiskinan para peternak leledi DesaNologatenyaitu menggunakan Asset-Based Community Development (ABCD). ABCD merupakan sebuah pendekatan dalam pengembangan masyarakat yang mengupayakan terwujudnya sebuah tatanan kehidupan sosial dimana masyarakat menjadi pelaku dan penentu perubahan sosial (social transformation)yang disebut juga dengan Community- Driven Development (CDD). Melalui pendekatan $\mathrm{ABCD}$, dalam proses pendampingan di Peternak menempatkan subyek dampingan untuk mengetahui apayang menjadi kekuatan yang dimiliki serta segenappotensi dan aset yang dipunyai yang potensial untuk dimanfaatkan. Sebab dengan mengetahui kekuatan dan asset, diharapkan subyek dampingan mengetahui dan bersemangat untuk terlibat sebagai aktor perubahan dan mamapu memiliki inisiatif dalam segala upaya meningkatkan kesejahteraan

Untuk melaksanakan program pendampingan, maka langkah-langkah yang digunakan dalam kegiatan pendampingan adalah ABCD (Aseet BassedCommunity Development), dilakukan setrategi sebagai berikut, Inkulturasi: Proses pertemuan dengan subyek dampingan. Biasa membudayakan bahan pakan yang ada di sekitar tempat tinggalmasyarakat. Adanya kebiasaan yasinan, tahlilan dan Arisan RT (pertemuan tiap malamjum,at) Pengajian tengah bulan purnama sebagai pertemuan tiap bulan.

To Descovery : Bersumber dari inovasi masyaarakat peternak ikan kolam dengan membuat makanan alternatif sebagai akibat mahalnya pakan jadi/kemasan(pelet) 
To Design: Perencanaan Pemahaman Kewirausahaan dan Kemandirian Komunitas melalui pelatihan-pelatihan dan pengetauhanmelalui internet.

To Define: Penguatan peteternak lele dengan pembuatan pakan alternatif dilakukan evaluasi oleh masyarakat peternak, dengan memnfaatkan kekuatan lokal (local wisdom) kegiatan yasinan tiap malam jum'at (yasinan), Arisan RT dan pertemuan bulanan pada tengah bulan purtama (lalilatulijtima).

\section{HASIL DAN PEMBAHASAN}

Kondisi subyek dampingan saat ini yaitu para peternak ikan lele sebagai, dengan kondisi sebagai berikut :

1. Selama ini para pelaku komonitas pemelihra ikan kolam di DesaNologaten menjadi lesu dikarenakan harga pakan semakin mingkat tajamditambahsituasisaatini,

2. Subyek dampingan saat ini masih belum banyak mendapatkan pengetahuan dan akses pembuatan makanan alternatif (rekayasa). Peternak juga belum banyak mendapatkan bimbingan untuk melek finansial (financial literacy),

3. peternak ikan belum memiliki rekam jejak yang baik dalam pengelolaan ikan kolam. Hal ini terbukti saat survey yang selama ini telah dilakukan menunjukkan adanya indikasi rendahnya kemampuan pengelolaan ternak ikan, yaitu sebagai berikut

Belum banyak memiliki kemampuan pengelolaan pemeiliharaan ternak ikan kolam,ukurankolam. Belum mampu mengidentifikasi persoalan akses tentang pembuatan pakan alternatif sebagai pengganti pakan ikan(pelet), Belum memiliki pengetahuan tentang usaha sampingan dari pemeliharaan ikan lele (ikan kolam ), Selama ini belum ada upaya pemberdayaan yang dilakukan oleh pihak-pihak terkait baik pemerintah maupu swasta yang mengembangkan usaha berbasis potensi lokal. Dan dampaknya selama ini tidak ada bentuk cluster-cluster/ kantong- kantongpengembaganwirausahausahayangberbasispotensilocal,

Selama ini belum ada upaya pendampingan kelembagaan yang dibuat perencanaan strategis untuk meningkatkan kelas kelompok usaha dari komonitas peternak ikan lele dan lele diharapkan mamapu pengentasan kemiskinan, Belum adanya pendampingan kepada para usaha kecil kominitas pemeliharan ternak ikan kolam di DesaNologaten yang tersistem. Dalam pengembangan masyarakat, dan satu sama lain saling menguatkan dan saling support antar peternak 
Berdasarkan kondisi dampingan saat ini, melalui program pendampingan peternak ikan lele, kondisi subyek dampingan yang diharapkan adalah mampu memiliki jiwa wira usaha dan terbebaskan dari kemiskinan Selanjutnya secara terperinci kondisi dampingan yang diharapkan adalah sebagai berikutMunculnya kesadaran para pelaku peternak ikan lele untuk berwirausaha yang menumbuhkan sikap kreatif, konsisten dengan pembuatan pakanalternatif.

Subyek dampingan mendapatkan pengetahuan dan akses pengelolaan pentani ikan lele dengan air kolam dengan indikasi, yaitu sebagai berikut: Adanya kepemilikian pengelolaan peternak ikan air kolam yangsehat. Memiliki pengetahuan tentang jaminan perekonomian, menujukesejahteraan Memiliki pemahaman tentang potensi pekarangan rumah pemanfaatanya untuk memlihara ikan lele dll, yang mampu menambah uang bulanan dan penghasilan rumahtangga.

Adanya upaya pemberdayaan yang dilakukan oleh pihak-pihak terkait baik pemerintah maupu swasta yang mengembangkan usaha berbasis potensi lokal.Dengan pemetaan asset komonitas ternak ikan kolam terpalmaka dampaknya adalah munculnya bentuk cluster-cluster/ kantong-kantong pengembagan usaha yang berbasis potensilokal.

Adapun tujuan dari kegiatan pendampingan pada Peternak setidaknya harus mencapai tiga tujuan pokokyaitu : peningkatan pengetahuan dan skill subyek pemberdayaan, peningkatan taraf hidup dan kesejahteraan subyek pemberdayaan dan kemandirian hidup.

Pencapaiantigatujuanintiini saling terkait sama lain, hanya saja tujuan pertama merupakan tujuan paling urgen di antara ketiganya. Tiga tujuan tersebut juga tersusun secara hirakis gambar sebagai berikut.

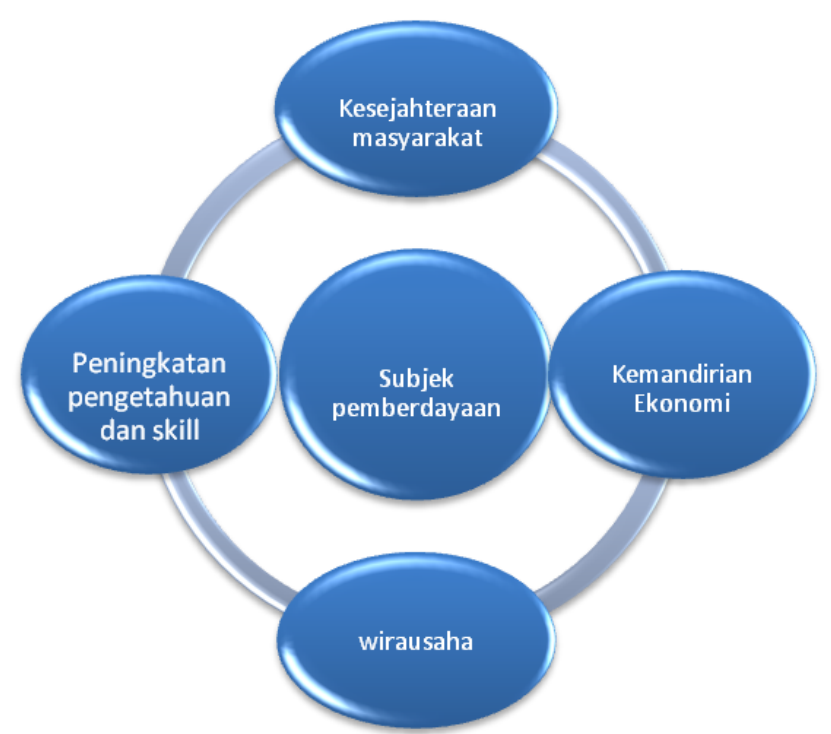

Gambar 1.4 pemberdayaan yang dilakukan 


\section{Peningkatan pengetahuan dan Skill subyek pemberdayaan}

Subyek pemberdayaan dalam sebuah program pemberdayaan tidak selalu padaposisi“"gelaskosong”. Artinya mereka bukanlah individu atau kelompok yang sama sekali tidak memeliki pengetahuan dan skill sama sekali. Berdasarkan hal ini, maka tujuan yang pertama kali harus tercapai adalah adanya peningkatan kapasitas diri, pengetahuan dan keterampilan subyek pemberdayaan. Meskipun kegiatan utama program pemberdayaan misalnya pada pemberdayaan dalam bidang ekonomi, namun tujuan utama yang pertama kali harus dicapai bukanlah peningkatan pendapatan, akan tetapi peningkatan pengetahuan dan keterampilan (Braunstein \& Welch, 2002, 445).

Tujuan untuk menjadikan subyek pemberdayaan menjadi individu ataukelompok yang well-educated sesuai dengan kapasitas mereka. Bila tujuan ini tercapai, maka subyek pemberdayaan akan bisa menyesuaikan diri dengan kehidupan dan problem yang dihadapi di lain waktu atau di lain tempat (Carter \& Jones-Evans, 2006).

Program pemberdayaan umumnya tidak jauh dari kegiatan ekonomi yang target dan tujuannya adalah adanya peningkatan kualitas hidup subyek pemberdayaan (Winoto \& Rachmawati, 2017). Subyek pemberdayaan dalam sebuah program pemberdayaan biasanya ditentukan dengan berbagai pertimbangan kriteria yang intinya mereka perlu dan segera didampingi dan diberdayakan. Pertimbangan umum biasanya kondisi pengetahuan dan ekonomi yang berada di bawah standar rata-rata.

Subyek pemberdayaan biasanya adalah masyarakat miskin, khususnya masyarakat masikin dalam kategori "miskin absolut". Pemberdayaan dan pengembangan masyarakat adalah pendekatan dalam program pembangunan yang bertujuan untuk meningkatkan kondisi kehidupan orang-orang di daerah tertentu. Ini juga merupakan strategi untuk menjangkau dan melibatkan desa dan masyarakat dalam proses membangun kehidupan mereka sendiri, yang akibatnya akan berkontribusi pada kemajuan nasional. Ini juga merupakan gerakan yang terkait dengan pemerintah lokal untuk mempromosikan kondisi kehidupan yang lebih baik bagi seluruh masyarakat dengan partisipasi aktif, dan inisiatif yang mungkin dari masyarakat

Program pemberdayaan harus dapat membawa perubahan bagikehidupan subyek pemberdayaan. Pemberdayaan dalam kegiatan ekonomi diharapkan mampu menjadi sarana peningkatan produktivitas kinerja, karya dan pendapatan mereka (Sukmaraga \& Hayati, 2011). Dengan adanya peningkatan produktivitas kerja dan karya maka akan dapat meningkatkan taraf hidup dan kesejahteraan. 


\section{Kemandirian hidup}

Kemandirian hidup subyek pemberdayaan merupakan tujuan akhir dan sekaligus menjadi target yang harus dicapai untuk menghindarkan mereka dari ketergantungan terhadap palaksana program, lingkungan dan ketergantungan terhadap pemberi bantuan, terutama dari pemerintah maupun non pemerintah(Trijono, 2001, 215-235). Artinya, pemberdayaan yang dilakukan dengan menggunakan kerjasama dengan pihak lain di luar komunitas seperti Lembaga Keuangan Syariah (BMT), Lembaga sosial kemasyarakatan yang mampu mendorong membuat mereka mandir idan pada akhir terlepas dari bantuan atau tidak tergantung pada pemberian (Trijono, 2001b),4). Dengan adanya kemandirian hidup,maka subyek pemberdayaan siap untuk" dilepas" oleh pelaksana program dan diharapkan mereka mampu membangkitkan jiwa wirausaha di kalangan komunitas.

\section{Kesimpulan}

Usaha budidaya ikan lele dengan menggu-nakan teknologi kolam terpal di lahan kering di Desa Nologaten mempunyai prospek cukup cerah dan layak dikembangkan. Berdasarkan Analisa keuangan, harga jual ikan lele konsumsi rataan per kilogram ditingkat pembudidaya pada luas kolam 12-16 $\mathrm{m}^{2}$ adalah $\mathrm{Rp} 10.394,74$, produksi yang dihasilkan pada luaskolam12$16 \mathrm{~m}^{2}$ adalah3.642,95ekor ikan lele konsumsi (setara 453,88kg ikan lele, perolehan pendapatan persiklus budidaya $\mathrm{Rp}$ 4.673.620,95 atau Rp1.557.874 dalam satu tahun periode budidaya (luaskolam12-16m²),Rp9.195.341atauRp3.065.114 dalam satu tahun periode keuntungan yangdiperolehRp832.668,59ataurataansenilaiRp277.556,20persiklusbudidaya(luaskolam12-

$16 \mathrm{~m}^{2}$ ),Rp2.248.907,48.ataurataansenilaiRp749.635,83 persiklus budidaya, Untuk memaksimalkan pendapatan pem-budidaya ikan lele, maka dilakukan penambahan jumlah danluas kolam dan mengembangkan usaha budidaya, menerapkan cara-cara pemeliha-raan dan budidaya yang baik, serta memperluas jangkauan pasar mulai dari konsumen perorang-an, pasar tradisional rumah makan dan restoran hingga kepasar modern Sekaresidenan Madiun.

Berdasarkan pelaksanaan pemberdayaan dilokasi pendampingan dapat disimpulkan sebagai berikut: 1) Komunitas peternak lele mendapatkan pengetahuan tentang tata cara pembuatan pakan alternatif untuk meningkatkan keutungan karena biaya pakan lebih murah.2) Memiliki pahaman tentang perhitungan secara ekonomi tentang penetapan harga pokok ikan lele, dengan menggunakan pakan alternatif buatan. Pakan alterenatif terdiri dari apas tahu, 3)Meningkatkan keterampilan tentang upaya penanggulangan dengan menggunakan pakan 
alternatif mendapatkan kesadaran bersama pentingnya kemandirian waarga komunitas, 4) Terbentuknya klaster kecil kelopok binaan untuk memudahkan kmunikasi kepada dalam pemberdayaan ekonomi kerakyatan, 5) Kesadaran bersama tentang jiwa kewirausahaan dalam mebangkitkan kesejahtraan komunitas.

\section{Daftar Pustaka}

Adomako, S., Danso, A., \& Ofori Damoah, J. (2016). The moderating influence of financial literacy on the relationship between access to finance and firm growth in Ghana. Venture Capital, 18(1), 43-61.

Boer, I., \& Adelina, P. N. (2014). Pemanfaatan Fermentasi Ampas Tahu Dalam Pakan Ikan Untuk Pertumbuhan Ikan Gurami Osphronemus Gourame Lac.2.

Braunstein, S., \& Welch, C. (2002). Financial literacy: An overview of practice, research, and policy. Fed. Res. Bull., 88,445.

Carter, S., \& Jones-Evans, D. (2006). Enterprise and small business: Principles, practice and policy. Pearson Education.

Dahmen, P., \& Rodríguez, E. (2014). Financial Literacy and the Success of Small Businesses: An Observation from a Small Business Development Center. Numeracy: Advancing Education in Quantitative Literacy,7(1).

Darman, S., Zakaria, F. R., \& Muhandri, T. (2015). Studi Kelayakan Pendirian Industri Kecil Pakan Ikan di Calingcing-Cianjur. MANAJEMEN IKM: Jurnal Manajemen Pengembangan Industri Kecil Menengah, 10(1),17-21.

Darmansah, A., Nugroho, T., \& Supriyono, E. (2016). Pemberdayaan masyarakat melalui pengembangan budi daya ikan lele di Desa Balongan, Indramayu, Jawa Barat. Agrokreatif: Jurnal Ilmiah Pengabdian kepada Masyarakat, 2(1), 8-16.

Dewi, N. (2014). Pendidikan Lingkungan Hidup bagi Masyarakat. Madiun (ID): IKIP PGRI Madiun.

Fatoki, O. (2014). The financial literacy of micro entrepreneurs in South Africa. Journal of social sciences, 40(2), 151-158.

Kusnadi, H. (2014). Pelatihan Pembuatan Pakan Ikan Lele, Mas, dan Nila. Bengkulu (ID): Dinas Peternakan dan Perikanan Kabupaten Rejang Lebong. 
